\title{
ANALISA BILANGAN PEROKSIDA TERHADAP KUALITAS MINYAK GORENG SEBELUM DAN SESUDAH DIPAKAI BERULANG
}

\author{
Husnah $^{1)}$, Nurlela ${ }^{2)}$ \\ ${ }^{1,2)}$ Dosen Program Studi Teknik Kimia Universitas PGRI Palembang \\ ${ }^{1)}$ email : husnahpgri@gmail.com \\ ${ }^{2)}$ email : lela_dj79@yahoo.co.id
}

\begin{abstract}
ABSTRAK
Minyak goreng merupakan salah satu produk pangan yang banyak dibutuhkan baik dalam rumah tangga maupun komersial karena termasuk salah satu kebutuhan pokok bagi manusia, terutama untuk proses penggorengan. Pada proses pemakaiannya minyak goreng umumnya dipakai berulang kali demi alasan ekonomi, walaupun hal tersebut pada batasan pengulangan tertentu memiliki efek terhadap kesehatan.Struktur fisik dan kimia minyak goreng dapat berubah komposisinya akibat penggunaan minyak goreng yang berulang- ulang. Beberapa perubahan yang terjadi pada minyak setelah penggorengan yaitu perubahan warna dan terurainya komponen penyusun minyak menjadi senyawa lain yaitu Free Fatty Acid. Pemakaian berulang dapat memicu terjadinya reaksi oksidasi, karena itu salah satu indikator untuk melihat penurunan mutu minyak goreng adalah bilangan peroksida. Angka peroksida atau bilangan peroksida merupakan suatu metode yâng biasa digunakan untuk menentukan degradasi minyak atau untuk menentukan derajat kerusakan minyak. Dari penelitian untuk Minyak Sebelum dipakai bilangan peroksida 0, 39, Sesudah dipakai :Penggorengan ikan ke - 1 , Penggorengan ikan ke -2 , Penggorengan ikan ke -3 bilangan peroksida berturut-turut $: 2,724: 3,578$ : 5,426 .
\end{abstract}

Kata kunci : Minyak goreng, reaksi Oksidasi, bilangan Peroksida.

\section{PENDAHULUAN}

Salah satu jenis palma yang banyak di gunakan Indonesia sebagai bahan baku minyak goreng nabati adalah Kelapa Sawit (Elaeis Quineesis Jacq) yang berasal dari kawasan Nigeria. Bangsa Belanda yang pertama membawa tanaman Kelapa Sawit ke Indonesia pada tahun 1884, dan mulai dikembangkan secara komersial oleh Andrien Hallet, seorang warga negara Belgia pada tahun 1991.

Kelapa Sawit merupakan salah satu sumber nabati yang penting selain jagung, kacangkacangan, dll. Selain itu kelapa sawit juga merupakan komoditi yang menyumbang devisa negara cukup banyak bagi negara. Umumnya, pemanfaatan minyak goreng oleh penjual makanan maupun dalam rumah tangga akan dilakukan secara berulang, hal ini didasari oleh nilai ekonomis yang diperoleh. Penggunaan minyak goreng secara berulang dalam jangka waktu yang lama dapat menyebabkan kerusakan minyak (Mulasari dan Utami, 2012). Kerusakan minyak selama proses menggoreng akan mempengaruhi kualitas dan nilai gizi dari bahan pangan yang digoreng.

Beberapa studi telah dilakukan untuk mengkaji hubungan minyak goreng bekas pakai dengan kesehatan, yakni keamanan bagi makhluk hidup. Pada minyak jelantah terdapat material tak berguna yaitu senyawa peroksida yang menyebabkan meningkatnya risiko terhadap beberapa penyakit, antara lain karsinoma (Rifqi T, Nabila YA, 2011). 
Pendistribusian minyak goreng curah yang selama ini dilakukan dalam bentuk tanpa kemasan, hal ini berarti minyak goreng curah sebelum digunakan banyak terpapar oksigen. Penggunaan minyak goreng oleh pedagang kecil maupun di rumah tangga dilakukan secara berulang-ulang, hal tersebut sangat memungkinkan terjadinya reaksi oksidasi yang lebih tinggi (Prasetyawan, 2007; Aminah dan Isworo, 2009). Salah satu parameter penurunan mutu minyak goreng adalah bilangan peroksida. Mengingat banyaknya penggunaan minyak goreng curah oleh masyarakat maka perlu dilakukan penelitian kualitas minyak goreng curah yang digunakan sebelum dan sesudah pemakaian berulang, khususnya dari parameter bilangan peroksida.

\section{TINJAUAN PUSTAKA}

Umumnya masyarakat menggunakan minyak goreng untuk mengolah makanan karena adanya anggapan masyarakat awam bahwa makanan yang digoreng akan terasa lebih gurih dan nikmat (Bangun, D, Memoar, 2010). Setiap produsen minyak goreng selalu mempromosikan bahwa produknya adalah produk yang terbaik dan menyehatkan, misalnya mengandung vitamin A, D dan E, Omega 3 dan 9, tidak mengandung kolesterol serta melalui dua kali proses penyaringan. Minyak kelapa sawit mengandung asam lemak tak jenuh dan asam lemak jenuh. Proses penyaringan minyak kelapa sawit sebanyak 2 kali (pengambilan lapisan lemak jenuh) menyebabkan kandungan asam lemak tak jenuh menjadi lebih tinggi. Tingginya kandungan asam lemak tak jenuh menyebabkan minyak mudah rusak ketika dipanaskan secara terus menerus pada suhu tinggi serta terjadinya kontak dengan oksigen dari udara luar yang memudahkan terjadinya reaksi oksidasi pada minyak.

Proses penggorengan secara berulang pada suhu yang relatif tinggi $\left(160^{\circ} \mathrm{C}-180^{\circ} \mathrm{C}\right)$ membuat penurunan kualitas minyak setelah digunakan. Penggunaan suhu tinggi selama penggorengan memacu terjadinya oksidasi minyak. Menurut deMan (1999) setiap peningkatan suhu $10^{\circ} \mathrm{C}$ laju kecepatan oksidasi meningkat dua kali lipat. Kecepatan oksidasi lemak makin bertambah dengan kenaikan suhu dan makin berkurang pada suhu rendah. Kecepatan akumulasi peroksida selama proses aerasi minyak pada suhu $100-115^{\circ} \mathrm{C}$ dua kali lebih besar dibanding pada suhu $10^{\circ} \mathrm{C}$ (Ketaren, 1986).

Peroksida terbentuk pada tahap inisiasi oksidasi, pada tahap ini hidrogen diambil dari senyawa oleofin menghasikan radikal bebas. Keberadaan cahaya dan logam berperan dalam proses pengambilan hidrogen tersebut. Radikal bebas yang terbentuk bereaksi dengan oksigen membentuk radikal peroksi, selanjutnya dapat mengambil hidrogen dari molekul tak jenuh lain menghasilkan peroksida dan radikal bebas yang baru. Peroksida dapat mempercepat proses timbulnya bau tengik dan bau yang tidak dikehendaki dalam bahan pangan. Jika jumlah peroksida lebih dari 100 meq peroksid/kg minyak akan bersifat sangat beracun dan mempunyai bau yang tidak enak. Kenaikan bilangan peroksida merupakan indikator bahwa minyak akan berbau tengik.

Bilangan peroksida adalah indeks jumlah lemak atau minyak yang telah mengalami oksidasi. Angka peroksida sangat penting untuk identifikasi tingkat oksidasi minyak. Minyak yang mengandung asam- asam lemak tidak jenuh dapat teroksidasi oleh oksigen yang menghasilkan suatu senyawa peroksida. Cara yang sering digunakan untuk menentukan angka peroksida adalah dengan metoda titrasi iodometri. Kerusakan minyak akan mempengaruhi kualitas dan nilai gizi makanan yang digoreng. Pemanasan minyak goreng dengan suhu yang sangat tinggi akan menyebabkan sebagian minyak teroksidasi. Minyak yang rusak akibat proses oksidasi akan menghasilkan makanan berwarna kurang menarik dan rasa yang tidak enak, serta kerusakan beberapa vitamin dan asam lemak esensial di dalam minyak. Proses oksidasi tersebut terjadi saat minyak tersebut mengalami kontak dengan sejumlah oksigen. Reaksi oksidasi juga akan menimbulkan bau tengik pada minyak dan lemak (Ketaren, S. 1986). Selain menimbulkan bau tengik, radikal bebas juga dapat terbentuk 
akibat oksidasi yang mempunyai dampak merusak sel dan jaringan tubuh. Hal ini disebabkan radikal bebas bersifat sangat reaktif (Retno, G, 1995).

Minyak goreng yang dipakai oleh masyarakat haruslah memiliki syarat atau memenuhi standar yang telah ditatapkan seperti tersaji pada Tabel 1 di bawah ini :

Tabel.1 Syarat Mutu Minyak Goreng

\begin{tabular}{|c|c|c|}
\hline Kriteria Uji & Satuan & Syarat \\
\hline Keadaaan bau, warna dan rasa & - & Normal \\
\hline Air & $\% \mathrm{~b} / \mathrm{b}$ & Maks 0,30 \\
\hline $\begin{array}{l}\text { Asam lemak bebas (dihitung } \\
\text { sebagai asam laurat) }\end{array}$ & & Maks 0,30 \\
\hline $\begin{array}{l}\text { Bahan makanan } \\
\text { tambahan }\end{array}$ & $\begin{array}{r}\text { Sesuai SN } \\
\text { No. } 72\end{array}$ & $\begin{array}{l}\text { an Permenkes } \\
\text { Per/IX/88 }\end{array}$ \\
\hline $\begin{array}{l}\text { Cemaran Logam } \\
\text { - Besi }(\mathrm{Fe}) \\
\text { - Tembaga }(\mathrm{Cu}) \\
\text { - Raksa }(\mathrm{Hg}) \\
\text { - Timbal }(\mathrm{Pb}) \\
\text { - Timah }(\mathrm{Sn}) \\
\text { - Seng }(\mathrm{Zn})\end{array}$ & $\begin{array}{l}\mathrm{Mg} / \mathrm{kg} \\
\mathrm{Mg} / \mathrm{kg} \\
\mathrm{Mg} / \mathrm{kg} \\
\mathrm{Mg} / \mathrm{kg} \\
\mathrm{Mg} / \mathrm{kg} \\
\mathrm{Mg} / \mathrm{kg}\end{array}$ & $\begin{array}{l}\text { Maks } 1,5 \\
\text { Maks } 0,1 \\
\text { Maks } 0,1 \\
\text { Maks 40,0 } \\
\text { Maks } 0,005 \\
\text { ks } 40,0 / 250,0)^{*}\end{array}$ \\
\hline $\operatorname{Arsen}(\mathrm{As})$ & $\% \mathrm{~b} / \mathrm{b}$ & Maks 0,1 \\
\hline Angka Peroksida & $4 \% \mathrm{mg} 02 / \mathrm{g}$ & Maks 1 \\
\hline
\end{tabular}

Sumber: Departeman Perindustrian (SNI 01-3741-1995)

*) Dalam kemasan kaleng

Pemakaian minyak secara berulang selalu menjadi hal yang dipertimbangkan karena secara ekonomi bisa menghemat pengeluaran, namun dibalik hal tersebut ternyata memiliki efek yang kurang baik bagi tubuh. Beberapa studi telah menunjukkan efek negatif lemak makanan teroksidasi pada manusia dan hewan percobaan. Oksidasi minyak menghasilkan oxygen-derived free radicals dan produk hidroksilasi yang selanjutnya menjadi FFA, aldehida dan keton yang menginduksi toksisitas organ. Studi oleh Adam (2008), menyatakan stres oksidatif yang disebabkan oleh pemanasan minyak dapat memodulasi peroksidasi lipid dan kadar lipoprotein, di mana terjadi peningkatan kadar kolesterol total, LDL, TG, asam lemak bebas, fosfolipid dan serebrosida dengan penurunan kadar HDL.

Paparan suhu tinggi dan oksigen pada minyak goreng akan memicu terjadinya reaksi oksidasi. Beberapa parameter terjadinya oksidasi seperti free fatty acid (FFA), komponen polar, asam konjugat dienoat meningkat pada setiap pengulangan penggorengan selama 60 kali periode penggorengan (Yoon dan Choe, 2007). 


\section{METODOLOGI PENELITIAN}

- Preparasi Minyak

1. Minyak yang akan dipakai sebagai bahan analisa terlebih dahulu dibagi menjadi dua bagian yaitu sebelum dipakai dan dipakai untuk menggoreng ikan.

2. Setelah dipisahkan dan dipakai untuk menggoreng ikan (3 kali penggorengan), minyak tersebut dibawa ke laboratorium untuk dilakukan analisa

- Analisa Bilangan Peroksida

1. Peralatan

- Neraca Analitik

- Erlenmeyer $250 \mathrm{ml}$

- Biuret

- Pipet Volume $30 \mathrm{ml}$

2. Bahan

- Larutan Asam Asetat dengan Kloroform, campurkan 3 bagian Asam Asetat dengan 2 bagian Kloroform

- Larutan Kalium Iodida jenuh

- Larutan Sodium Thiosulfat $\left(\mathrm{Na}_{2} \mathrm{~S}_{2} \mathrm{O}_{3} .5 \mathrm{H}_{2} \mathrm{O}\right) 0.01 \mathrm{~N}$ yang telah distandarisasi sebelum digunakan

- Larutan indikator Starch yang telah dicampur dengan air destilasi

3. Prosedur

- Timbang sampel sebanyak $5 \pm 0.05$ gram ke dalam erlenmeyer yang tertutup dan kemudian tambahkan $30 \mathrm{ml}$ larutan campuran Asam Asetat dengan Kloroform dan aduk hingga semua sampel larut. Tambahkab $0.5 \mathrm{ml}$ larutan Kalium Iodidia jenuh dengan pipet tetes.

- Kocok erlenmeyer tersebut selama 1 menit dan kemudian tambahkan $30 \mathrm{ml}$ aquadest.

- Titrasi dengan larutan Natrium Thiosulfat $0.01 \mathrm{~N}$ secara konstan dan kocok dengan baik sampai warna kuning hampir hilang (kuning pucat). Tambahkan larutan kanji dan lanjutkan itrasi dengan tetap dikocok sampai titik akhir titrasi untuk membebaskan semua Iodine yang berada dilapisan Kloroform, tambahkan setetes demi setetes larutan Natrium thiosulfat sampai warna birunya hilang.

4. Perhitungan

$$
\mathrm{POV}=\underline{\mathrm{V} \times \mathrm{N} \times 1000}
$$

W

Dimana: $\quad \mathrm{V}=$ Volume Titrasi sampel

$\mathrm{N}=$ Normalitas larutan $\mathrm{Na}_{2} \mathrm{~S}_{2} \mathrm{O}_{3} .5 \mathrm{H}_{2} \mathrm{O}$

$\mathrm{W}=$ Berat Sampel 
5. Diagram Alir

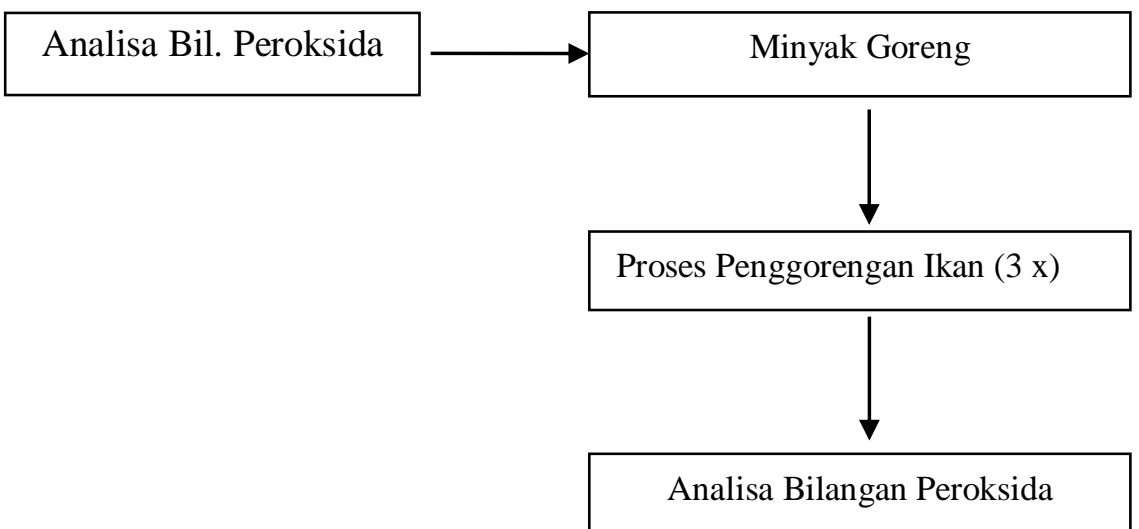

Gambar 1. Diagram Alir Penelitian

\section{PEMBAHASAN}

A. Hasil Penelitian

- Analisa Bilangan Peroksida minyak sebelum dipakai

Diketahui : $\mathrm{W}=5,4815 \mathrm{gr}$

$\mathrm{V}=0,18 \mathrm{ml}$

$\mathrm{N}=0,119 \mathrm{~mol} / \mathrm{ml}$

Perhitungan :

$\mathrm{POV}=\underline{0,18 \mathrm{ml} \times 0,119 \mathrm{~mol} / \mathrm{ml} \times 1000 \mathrm{~g} / \mathrm{mol} . \mathrm{meq}}$

$\mathrm{POV}=0,39 \mathrm{meq}$

$5,4815 \mathrm{gr}$

- Minyak sesudah dipakai menggoreng ikan

1. Sampel ikan pertama

Diketahui : $\quad \mathrm{W}=5,1547 \mathrm{gr}$

$$
\begin{aligned}
\mathrm{V} & =1,18 \mathrm{ml} \\
\mathrm{N} & =0,119 \mathrm{~mol} / \mathrm{ml}
\end{aligned}
$$

Perhitungan :

$P O V=\underline{1,18 \mathrm{ml} \times 0,119 \mathrm{~mol} / \mathrm{ml} \times 1000 \mathrm{~g} / \mathrm{mol} \cdot \mathrm{meq}}$

$$
5,1547 \mathrm{gr}
$$

$\mathrm{POV}=2,724 \mathrm{meq}$

2. Sampel ikan kedua

Diketahui : $\quad \mathrm{W}=6,3517 \mathrm{gr}$

$\mathrm{V}=1,91 \mathrm{ml}$

$\mathrm{N}=0,119 \mathrm{~mol} / \mathrm{ml}$

Perhitungan :

$P O V=\underline{1,91 \mathrm{ml} \times 0,119 \mathrm{~mol} / \mathrm{ml} \times 1000 \mathrm{~g} / \mathrm{mol} . \mathrm{meq}}$

$6,3517 \mathrm{gr}$

$\mathrm{POV}=3,578 \mathrm{meq}$

3. Sampel ikan ketiga 


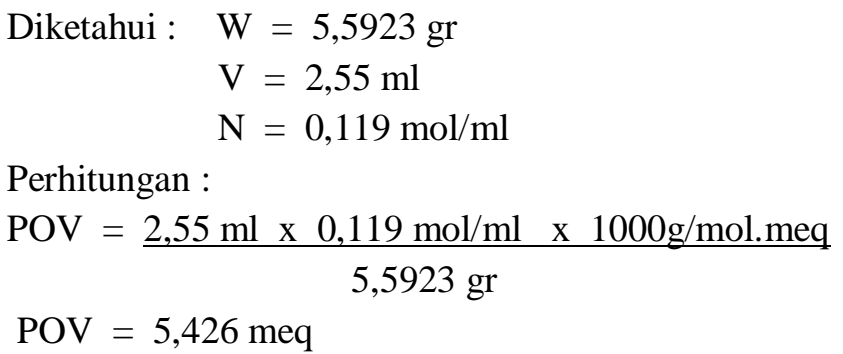

\section{B. Pembahasan}

Dari hasil perhitungan bilangan peroksida di atas maka dapat dibuat dalam bentuk tabel dan diagram batang di bawah ini :

Tabel 2. Perhitungan hasil penelitian bilangan peroksida minyak sebelum dan sesudah dipakai berulang

\begin{tabular}{|l|c|}
\hline \multicolumn{1}{|c|}{ Jenis Sampel } & Bilangan peroksida \\
\hline Sebelum dipakai & 0,39 \\
\hline Sesudah dipakai : & \\
- Penggorengan ikan ke -1 & 2,724 \\
- Penggorengan ikan ke -2 & 3,578 \\
- Penggorengan ikan ke -3 & 5,426 \\
\hline
\end{tabular}

Berdasarkan tabel 2. diatas maka dapat dilihat bahwa minyak goreng sebelum pemakaian, bilangan peroksidanya masih memenuhi standar, sementara setelah pemakaian ke -1 sampai ke -3 untuk menggoreng ikan, bilangan peroksida mengalami peningkatan dan diatas nilai maksimum yang diperbolehkan berdasarkan tabel 1 diatas.

Hasil analisis terhadap bilangan peroksida cenderung meningkat, dengan semakin banyak pengulangan penggoregan. Hal tersebut merupakan indikator minyak telah mengalami oksidasi dan hidrolisis selama penggorengan. Bilangan peroksida pada batas tertentu akan memberikan aroma yang tidak dikehendaki, bahkan berefek negatif terhadap kesehatan manusia. Ketaren (1986) menyatakan terjadinya oksidasi mengakibatkan bau tengik pada minyak dan lemak. Oksidasi dimulai dari pembentukan peroksida dan hidroperoksida. Tingkat selanjutnya ialah terurainya asam-asam lemak disertai dengan konversi hidroperoksid menjadi aldehid dan keton serta asam-asam lemak bebas.
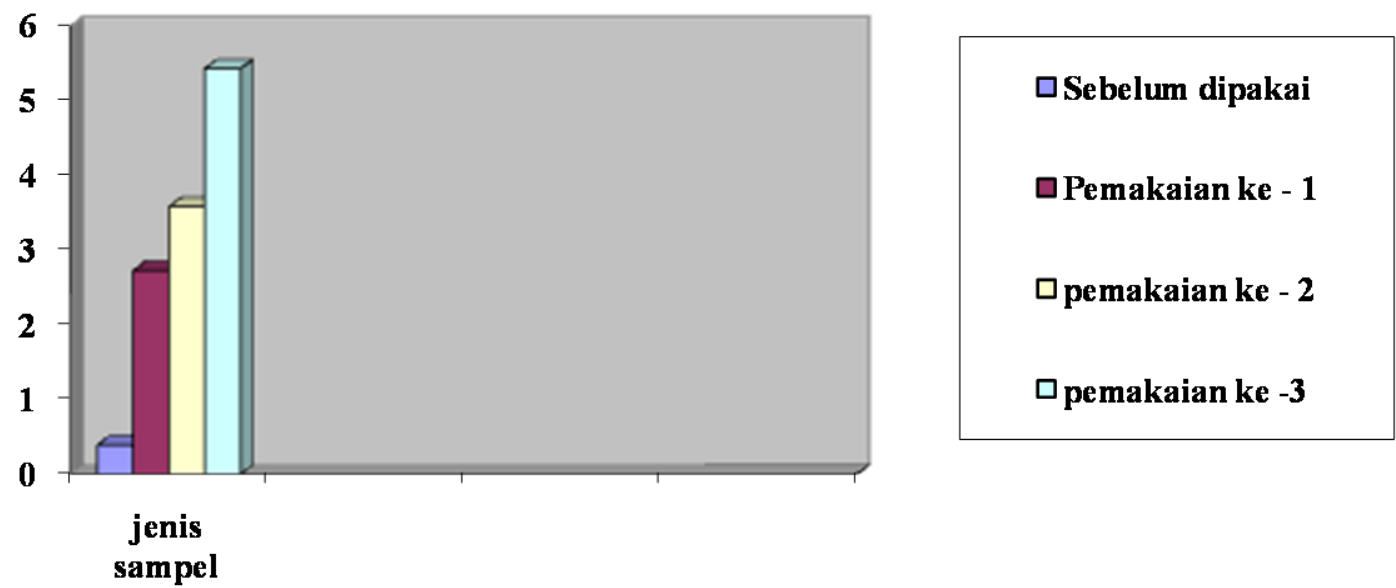

Gambar 1. Diagram batang hasil penelitian bilangan peroksida minyak sebelum dan sesudah dipakai berulang 
Aldehid berperan dalam pembentukan ketengikan, malonaldehid yang dapat diuji sebagai kadar TBA. Jika jumlah peroksida lebih dari $100 \mathrm{meq}$ peroksid/kg minyak akan bersifat sangat beracun dan mempunyai bau yang tidak enak. Kenaikan bilangan peroksida merupakan indikator bahwa minyak akan berbau tengik (Ketaren 1986). Menurut Raharjo (2004) kerusakan aroma minyak kedelai akibat autooksidasi baru mulai terdeteksi secara inderawi ketika angka peroksidanya mencapai 10 atau lebih

\section{KESIMPULAN}

Penggunaan suhu tinggi selama termasuk penggorengan menyebabkan turunnya kualitas minyak goreng. Penurunan ini bisa dilihat dari perhitungan bilangan peroksida, dimana ternyata semakin banyak pengulangan penggorengan bilangan peroksida semakin meningkat yang mengindikasikan bahwa minyak goreng tersebut tidak memenuhi standar yang ditentukan. Hal ini terkait dengan terjadinya reaksi oksidasi dan hidrolisa yang terjadi pada minyak goreng selama proses penggorengan terutama pada penggorengan berulang.

\section{DAFTAR PUSTAKA}

Aminah, S., dan Isworo T.J. 2009. Praktek Penggorengan dan Mutu Minyak Goreng Sisa pada Rumah Tangga Rt.05 Rw. III Kedungmundu Tembalang Semarang. Laporan penelitian Internal UNIMUS Tahun 2009.

Bangun, D, Memoar “Duta Besar” Sawit Indonesia, Jakarta: Penerbit Buku Kompas, 2010.

Departemen Perindustrian Republik Indonesia (SNI 013741 1995)

Ketaren, S. 1986. Minyak dan Lemak Pangan, Penerbit Universitas Indonesia (UI Press), Jakarta.1986.

Mulasari, A.S., \& Utami, R.R. 2012. Kandungan Peroksida pada Minyak Goreng di Pedagang Makanan Gorengan Sepanjang Jalan Prof. Dr. Soepomo Umbulharjo Yogyakarta. Arc. Com. Health. Vol. 1 No.2:120-123.

Prasetyawan, E.A. 2007. Uji Kualitas Minyak Goreng Pada Para Penjual Gorengan di lingkungan Kampus Universitas Jember. http://digilib.unej.ac.id. Diakses 13 Nopember 2008

Raharjo, S., 2006. Kerusakan Oksidatif pada Makanan. Gadjah Mada University Press. Yogyakarta.

Retno, G, Radikal bebas-sifat dan peran dalam menimbulkan kerusakan-kematian sel, Cermin Dunia Kedokteran 102, 1995.

Rifqi T, Nabila YA. Banana peels: An economical refining agent for carcinogenic substance in waste cooking oil. APEC Youth Scientist Journal 2011; 4(1): 62 -73.

Yoon, Y., and Choe, E. 2007. Oxidation of Corn Oil During Frying of Soy-Flour-Added Flour Dough. Journal of Food Science. Vol 72, Nr.6, Institut of Food Technologists. 